\title{
Comparative study of the ovarian morphology in the order Polydesmida (Diplopoda) and description of unusual structures in the female reproductive system
}

\author{
Pinheiro, TG. ${ }^{a}$, Marques, MI. ${ }^{b}$ and Fontanetti, CS. ${ }^{a,{ }^{*}}$ \\ ${ }^{a}$ Universidade Estadual Paulista “Júlio de Mesquita Filho” UNESP, Campus de Rio Claro, CEP 13506-900 \\ Rio Claro, SP, Brazil \\ ${ }^{b}$ Instituto de Biociências, Cuiabá, Programa de Pós-graduação em Ecologia e Conservação da Biodiversidade, \\ Universidade Federal de Mato Grosso, CEP 78060-900 Cuiabá, MT, Brazil \\ e-mail:fontanet@rc.unesp.br
}

Received September 13, 2012 - Accepted May 16, 2013 - Distributed November 29, 2013

(With 3 figures)

\begin{abstract}
Polydesmida is the largest order in the class Diplopoda in terms of the number of species, genera and families, but there are few studies of the ovarian morphology of species in this order. This study aimed to perform a comparative study of the ovarian morphology of three species from this order to increase the understanding of the morphological evolution of this system in Polydesmida. Adults females of two of these species, Poratia salvator and Myrmecodesmus hastatus, belonging to the family Pyrgodesmidae, had a unpaired ovary that formed a tubular organ containing oocytes, with $P$. salvator present grouping of oocytes into a structure similar to ovisacs. This condition appeared to be apomorphic and was associated with the small size of these species $(<10 \mathrm{~mm})$ and their short life cycle. The third species, Telonychopus klossae (Chelodesmidae), had a large body and an ovary with paired ovisacs, which was symplesiomorphic with other Polydesmida families.
\end{abstract}

Keywords: apomorphy, millipedes, reproduction, synapomorphy.

\section{Estudo comparativo da morfologia ovariana na ordem Polydesmida (Diplopoda) e descrição de estruturas incomuns do sistema reprodutor feminino}

\section{Resumo}

A ordem Polydesmida é a maior da classe Diplopoda em número de espécies, gêneros e famílias, entretanto existem poucos estudos sobre a morfologia ovariana de suas espécies. Esta pesquisa tem como objetivo realizar um estudo comparativo sobre a morfologia ovariana de três espécies dessa ordem a fim de contribuir para discussões sobre a evolução morfológica deste sistema no grupo. Duas dessas espécies, Poratia salvator e Myrmecodesmus hastatus, representantes da família Pyrgodesmidae, apresentam ovário como um órgão tubular único, com a primeira possuindo os ovócitos agrupados em uma estrutura semelhante a ovissacos. Esta condição parece ser uma apomorfia aparentemente associada ao tamanho diminuto dos animais destas espécies (menos de $10 \mathrm{~mm}$ ) e suas histórias de vida curtas. A terceira espécie, Telonychopus klossae, um quelodesmídeo de tamanho corporal grande, possui um ovário pareado com presença de ovissacos, condição simplesiomórfica semelhante à de outras famílias de Polydesmida.

Palavras-chave: apomorfia, milípedes, reprodução, sinapomorfia.

\section{Introduction}

The ovarian morphology of the Diplopoda has been used to support discussions of the phylogenetic relationships within this group, comparisons between two subclasses of millipedes (Chilognata and Penicillata) and comparisons with other classes within Arthropoda (Yahata and Makioka, 1994, 1997; Freitas et al., 2003). However, there have only been a few morphological studies of the female reproductive system of species in this group, which were restricted mostly to Asian species (Freitas et al., 2003).
This shortage of studies is particularly pronounced in the order Polydesmida. This is the most diverse order among the Diplopoda; however, there have only been five reports on the ovarian morphology of species in this order (Miley, 1930; Seifert, 1932; Kubrakiewcz, 1987; Nair, 1981).

Millipede females have reproductive organs located between the digestive tract and central nervous cord, which opens into the third body segment just behind the second pair of legs (Hopkin and Read, 1992). Unlike in other Myriapoda, where the ovary is a single tubular or- 
gan, the ovaries of millipedes are described as unpaired structures (Newport, 1841; Nadarajalingam and Subramonian, 1984; Kubrakiewicz, 1987, 1991a, b; Yahata and Makioka, 1994, 1997; Freitas et al., 2003) and as paired structures (Miley, 1930; Seifert, 1932; Fontanetti et al., 2010). In some species, the oocytes are distributed in two paired strands in the immature ovary, but gradually lose their symmetry due to the developing of the oocytes (Nair, 1981; Fontanetti and Cunha, 1993; Gealekman et al., 1996; Warburg and Gealekman 2000).

The order Polydesmida contains 5,480 species, 1,437 genera and 30 families (Hoffman et al., 2002; Shelley, 2003). The adults range from 2 to $130 \mathrm{~mm}$ in length and many families have a wide variety of colours and shapes. They mostly inhabit the soil surface and litter, but a few are strictly arboreal (Hoffman et al., 1996, 2002). Many of the species have a short life cycle, which is completed within one year (Adis et al., 2000; Bergholz, 2007; Battirola et al., 2009; Pinheiro et al., 2009). An important reproductive characteristic of many species in this order is the construction of nests for egg protection, mainly against variations in humidity and temperature (Bano and Krishnamoorthy, 1985; Vohland and Adis, 1999; Voigtlander, 2000; Pinheiro et al., 2009).

There is a lack of information available on the ovarian morphology of neotropical species of millipedes and the different configurations of the reproductive organs in this class. Thus, this study aimed to conduct a comparative study of the ovarian morphology of three species in this order: Poratia salvator Golovatch \& Sierwald, 2000, Myrmecodesmus hastatus (Schubart, 1945) (both Pyrgodesmidae) and Telonychopus klossae Hoffman, 1965 (Chelodesmidae) to facilitate discussions on the morphological evolution of this system in Polydesmida.

\section{Material and Methods}

Poratia salvator and M. hastatus were collected in Brazil from the Base Avançada de Pesquisas do Pantanal, which belongs to the Universidade Federal de Mato Grosso, and SESC Baía das Pedras, a unit of the Estância Ecológica SESC Pantanal in the municipalities of Barão de Melgaço and Poconé in the north of the Pantanal, Mato Grosso, Brazil. Telonychopus klossae was collected in the city of Cuiabá-MT at the Universidade Federal de Mato Grosso, Brazil.

All species were collected in 2011 and maintained in plastic containers covered by lids and containing a small amount of organic matter. The specimens were identified and separated based on species, sex and development time. They were transported in a polystyrene insulated box to the Department of Biology, Universidade Estadual Paulis “Júlio de Mesquita Filho" UNESP, Campus Rio Claro, São Paulo state, Brazil.

Females were anaesthetised with ethyl ether and dissected in physiological solution to remove their ovaries. For ultramorphological analysis, samples were fixed with glutaraldehyde solution in a $2.5 \%$ solution of $0.1 \mathrm{M}$ sodium cacodylate buffer $(\mathrm{pH} 7.2)$ at $4^{\circ} \mathrm{C}$ for at least $2 \mathrm{~h}$.
Samples were then dehydrated using an ascending series of acetone solutions with concentrations of $50 \%, 75 \%$, $90 \%$ and $95 \%$ for $10 \mathrm{~min}$ each, followed by three $10 \mathrm{~min}$ immersions in $100 \%$ acetone. Samples were subjected to critical point drying and sputter-coated. Images were acquired using a TM-3000 (Hitachi High Technologies) low vacuum bench scanning electron microscope (SEM).

To complement and correct establishment of ovarian morphology, the ovaries were processed for histological examination with the material being fixed in alcoholic Bouin solution, dehydrated in ethanol series and stained with hematoxylin and eosin. The slides were analysed under a light microscope, and the images were captured using Leica IM50 software, version 5 Release 220, in order to record the results.

\section{Results}

The ovary of $P$. salvator was an unpaired structure (see Figures 1A, D), but it was noteworthy that oocytes at different stages of development appeared to be grouped, independently of each other, into a structure that was similar to an ovisac (see Figures 1A, B, E). The ovisacs were coated with a very thin membrane that was associated with numerous tracheoles (see Figures 1B, C). The ovisacs were in close contact with the fat body, which was not highly developed in this species (see Figure 1A). The corium of the oocytes lacked ornamentation (see Figures 1B, C).

The ovary of $M$. hastatus was also an unpaired structure (see Figures 2A, D), but there was no clustering of oocytes into ovisacs (see Figures 2A, D). The organ was immersed in the fat body, which was well developed in this species (see Figures 2A, B). The surface of the oocytes had an irregular appearance (see Figure 2C). Numerous tracheoles were also associated with the ovary in this species (see Figures 2B, C).

Telonychopus klossae had paired ovaries (see Figures $3 \mathrm{~A}, \mathrm{~B}$ ) and the oocytes at different stages of development were grouped into ovisacs (see Figures 3B, C, D). The fat body was well developed in this species and it was in close contact with the ovaries (see Figures 3A, B). The oocytes were clustered within a membrane, which gave the appearance of trusses (see Figures 3B, D). For the first time, the presence of micropyles was observed in Diplopoda (arrows and detail in Figure 3C). The surface of the oocytes was uniform and it lacked ornamentation (see Figures 3C, D).

\section{Discussion}

Poratia salvator and M. hastatus are both very small species $(<10 \mathrm{~mm})$ and their ovaries formed an unpaired structure. However, $P$. salvator possessed a structure that was similar to an ovisac, which is an unprecedented feature in millipede species with unpaired ovaries.

The presence of a unpaired ovary and the absence of ovisacs in M. hastatus has also been described for the following species: in the order Polyxenida (Polyxenidae), Eudigraphis nigricans (Miyosi, 1947) (Yahata and 

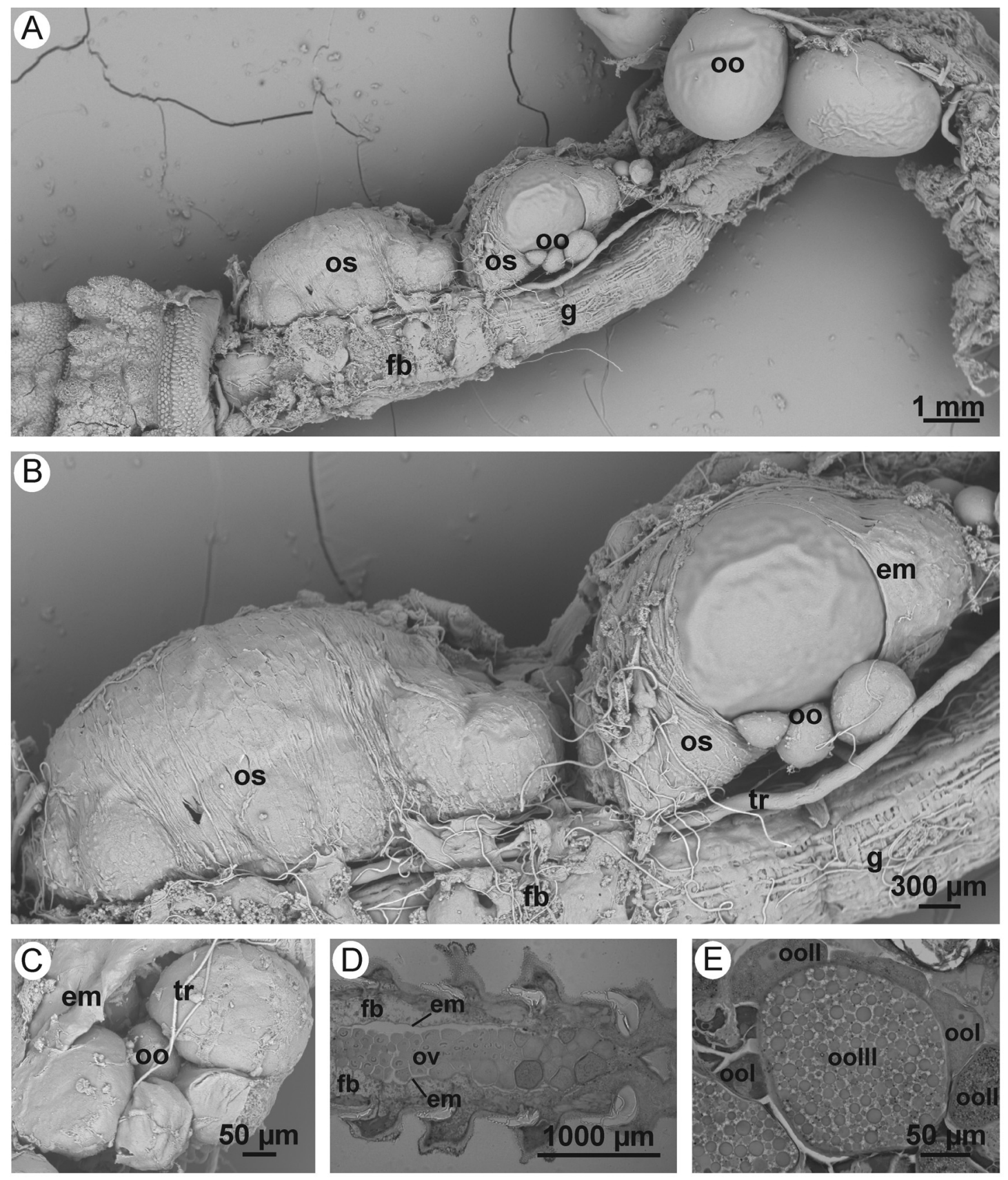

Figure 1 - A-C: Poratia salvator ovary; D-E: histological sections of $P$. salvator. (A) Ovarian positioning and general structure of well-developed oocytes; (B) ovisacs; (C) detail of undeveloped oocytes; (D) ovarian general structure and oocyte distribution; (E) detail of an ovisac. em: external membrane; fb: fat body; g: gut; oo: oocyte; ooI: oocyte in stage I; ooII: oocyte in stage II; ooIII: oocyte in stage III; os: ovisac; ov: ovary; tr: tracheole.

Makioka, 1994) and Polyxenus lagurus (Linnaeus, 1758) (Kubrakiewcz, 1991b); in the order Glomerida (Doderiidae) Hyleoglomeris japonica Verhoeff, 1936 (Yahata and Makioka, 1997); in the order Spirostreptida "Spirostreptus" asthenes Pocock, 1892 (Spirostreptidae) (Nadarajalingam and Subramonian, 1984), Pseudonannolene tocaiensis Fontanetti, 1996 and P. tri- color Brölemann, 1901 (Pseudonannolenidae) (Freitas et al., 2003); and in the order Julida (Julidae), Julus terrestris Linnaeus, 1758 (Newport, 1841) and Ophyiulus pilorus (Newport, 1842) (Kubrakiewcz, 1991a).

In the order Polydesmida, the unpaired ovary is known only in one species in the Paradoxosomatidae, 
Oxidus gracilis (C.L. Koch, 1847) (=Orthomorpha gracilis) (Kubrakiewcz, 1987). Another Paradoxosomatidae species, Anoplodesmus splendidus
(Verhoeff, 1936) (=Jonespeltis splendidus), has one paired ovary in newly moulted females that loses the
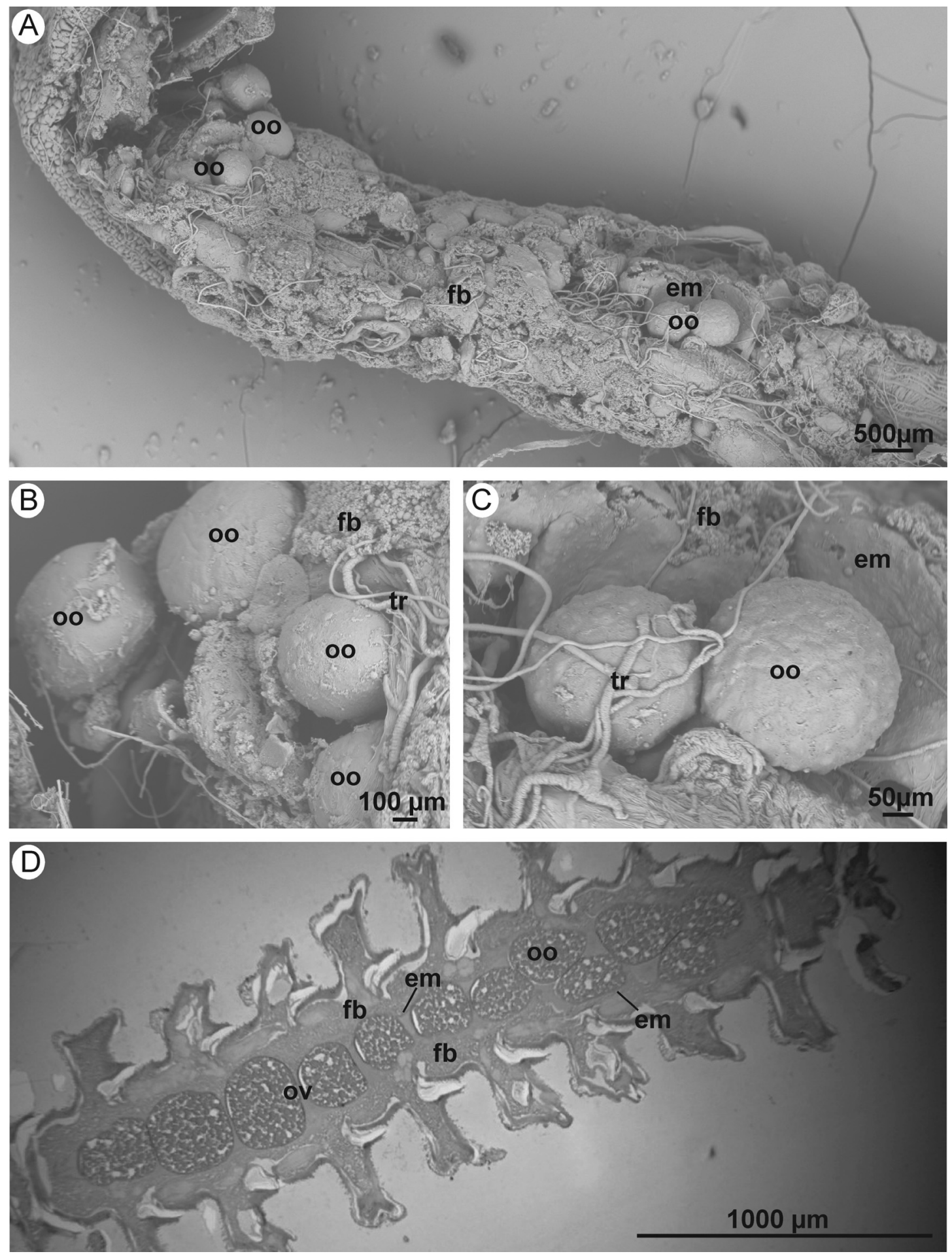

Figure 2 - A-C: Myrmecodesmus hastatus ovary; D: histological section of M. hastatus. (A) Ovarian positioning and general structure; (B) detail of the ovary in close contact with the fat body; (C) detail of the irregular surface of oocytes; (D) oocyte distribution. em: external membrane; fb: fat body; oo: oocytes; ov: ovary; tr: tracheoles. 

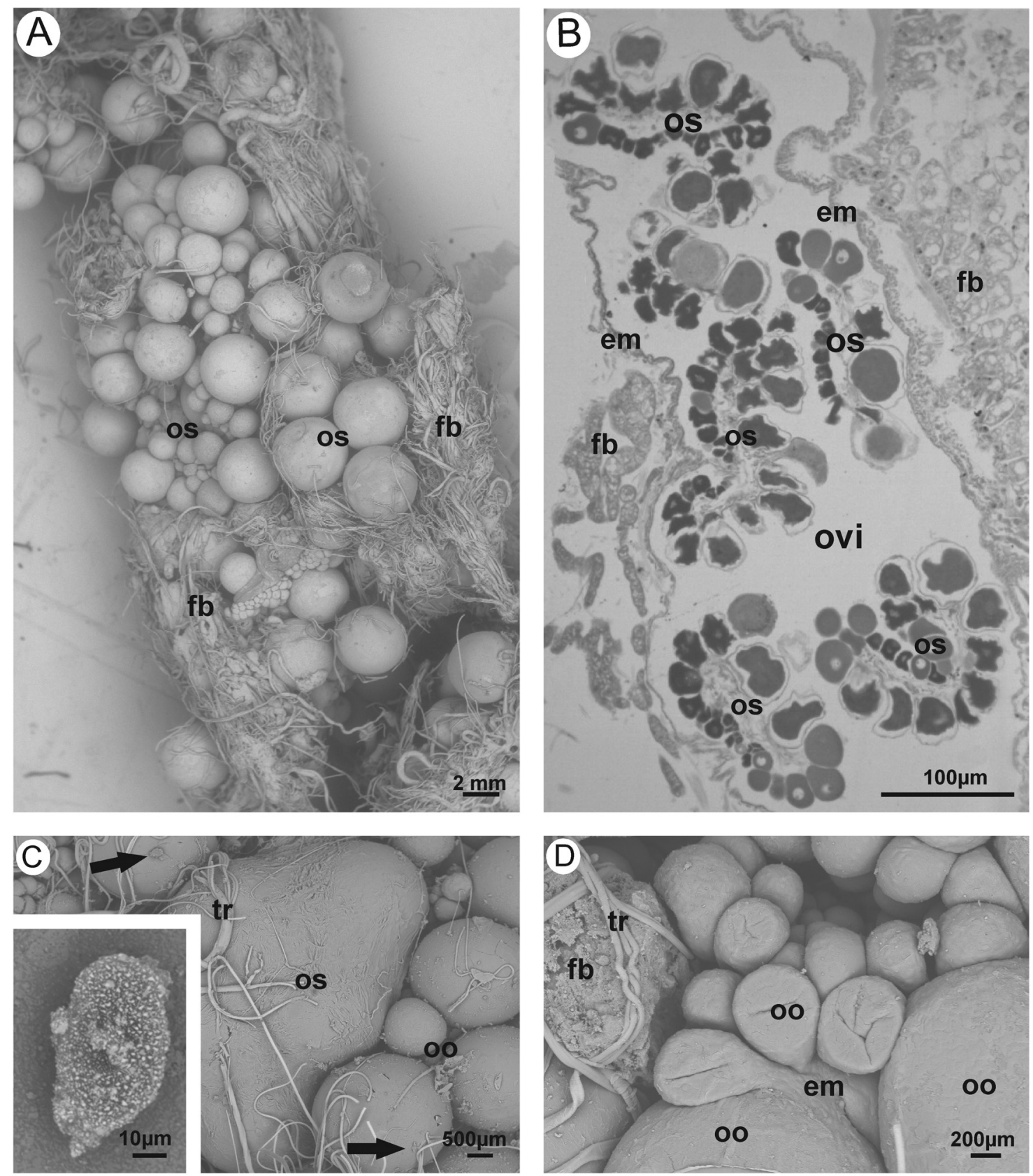

Figure 3 - A, C and D: Telonychopus klossae ovary; B: histological section of T. klossae ovary. (A) Ovarian general structure and oocytes in different development stages, clustered by a membrane; (B) distribution of paired ovaries; (C) intact ovisac and micropyle features; (D) oocytes in different development stages, grouped by a membrane. em: external membrane; fb: fat body; oo: oocytes; os: ovisac; ovi: oviduct; tr: tracheoles; arrows in C: micropyle.

symmetry conforming advances the oocytes development, becoming into an unpaired structure (Nair, 1981).

This might suggest that the possession of ovaries with an unpaired structure by species in the family Pyrgodesmidae is an apomorphic condition, which probably reflects the small size of individuals in this family $(<10 \mathrm{~mm})$ and their short lifespan of about 3 months (Adis et al., 2000; Pinheiro et al., 2009). An apomorphic condition with an unpaired ovary was also suggested by Freitas et al. (2003) for Pseudonannolene spp., which have unpaired ovaries without pairing of the germarium, and this is considered by other authors to be the most derived model among the millipedes. According to Sareen and Adiyodi (1983) and Kubrakiewicz (1987), this condition may be an evolutionary specialisation because it appears in several independent Myriapoda groups. 
However, the pairing of the mature ovary observed in T. klossae has also been observed in other species in the order Polydesmida, i.e., Euryurus erythropygus (Brandt, 1841) (=Euryurus carolinensis) (Euryuridae) (Miley, 1930), Strongylosoma pallipes (Olivier, 1792) (Paradoxosomatidae) (Seifert, 1932).

Based on this information, it may be suggested that, in contrast to the claim of Fontanetti and Cunha (1993), the morphology of the female millipede reproductive system is not constant among families, and follows the same trends that are found in the male reproductive system, which are also highly diverse (Kanaka and Chowdaiah, 1974; Freitas et al., 2003; Fontanetti, 1991; Freitas and Fontanetti, 2005).

\section{Acknowledgments}

The authors would like to thank Gerson Mello, Cristiane Milleo, Antônio Yabuki and Mônika Iamonte for technical support; Professor Sergei Golovatch (Moscow, Russia) and Fernando José Zara (UNES Jaboticabal, São Paulo, Brazil), who kindly helped with the editing and proofreading of this study; the Fundação de Amparo à Pesquisa do Estado de São Paulo (FAPESP) for the scholarship provided to the first author; CNPq; Instituto de Ciência e Tecnologia em Áreas Úmidas (INAU/MCT/CNPq/UFMT) and PRONEX (FAPEMAT/CNPq) for financial support provided to the project.

\section{References}

ADIS, J., GOLOVATCH, SI., LARS, W. and HANSEN, B., 2000. On the identities of Muyudesmus obliteratus Kraus, 1960 vs. Poratia digitata (Porat, 1889), with first biological observations on parthenogenetic and bisexual populations (Diplopoda: Polydesmida: Pyrgodesmidae). In WYTWER, J. and GOLOVATCH, SI. (Eds.). Progress in studies on Myriapoda and Onychophora. Warszawa: Fragmenta Faunistica (Supplement), no. 43, p. 149-170.

BANO, K. and KRISHNAMOORTHY, RV., 1985. Reproductive strategy and life history of Jonespeltis splendidus (Verhoeff) (Diplopoda: Polydesmida) with environmental synchronization. Journal of Soil Biology and Ecology, vol. 5 , no. 1, p. 48-57.

BATTIROLA, LD., MARQUES, MI., ROSADO-NETO, GH., PINHEIRO, TG. and PINHO, NGC., 2009. Vertical and time distribution of Diplopoda (Arthropoda, Myriapoda) in a monodominant forest in Pantanal of Mato Grosso, Brazil. Zoologia, vol. 26, p. 479-487.

BERGHOLZ, NGR., 2007. Ecological traits and genetic variation in Amazonian populations of the Neotropical millipede Poratia obliterata (Kraus, 1960) (Diplopoda: Pyrgodesmidae) (Brazil). Sofia: Pensoft Plubishers. 197 p. Invertebrate Ecology \& Conservation Monographs.

FONTANETTI, CS., 1991. Morphology of testicles of some Brazilian species of Diplopoda and their phylogenetic relations. Revista Brasileira de Zoologia, vol. 7, p. 541-544.

FONTANETTI, CS. and CUNHA, MAS., 1993. Morfologia ovariana e desenvolvimento dos ovócitos de Rhinocricus padbergi Verhoeff (Diplopoda, Spirobolida, Rhinocricidae). Revista Brasileira de Biologia, vol. 53, no. 1, p. $7-12$.
FONTANETTI, CS., SOUZA, T da S., CALLIGARIS, IB. and BOZZATTO, V., 2010. Ovarian morphology and oogenesis dynamic of the diplopod Urostreptus atrobrunneus Pierozzi \& Fontanetti, 2006 (Spirostreptidae), a potential plague in urban centers. Animal Biology, vol. 60, p. 467-478.

FREITAS, VC. and FONTANETTI, CS., 2005. Testicular morphology and histochemical of Pseudonannolene tocaiensis Fontanetti, 1996 (Diplopoda, Pseudonannolenidae). Naturalia, vol. 28-30, p. 24-27.

FREITAS, VC., ZIRONDI, MC. and FONTANETTI, CS., 2003. Ovarian morphology in two species of Pseudonannolene (Diplopoda, Arthropoda). Brazilian Journal of Morphological Sciences, vol. 20, no. 3, p. 153-156.

GEALEKMAN, O., TICHOMIROVA, E. and WARBURG, M. 1996. Phenology and reproduction of the iulid millipedes Catamicrophyllum spp. inhabiting the Mediterranean region in northern Israel. Israel Journal of Zoology, vol. 42, p. 66.

HOFFMAN, RL., GOLOVATCH, SI., ADIS, J. and MORAIS, JW., 1996. Pratical keys to the orders and families of millipedes of the Neotropical region (Myriapoda: Diplopoda). Amazoniana, vol. 14, no. 1-2, p. 1-35.

HOFFMAN, RL., GOLOVATCH, SI., ADIS, J. and MORAIS, JW., 2005. Diplopoda. In ADIS, J. (Eds.). Amazonian Arachnida and Myriapoda. Sofia: Pensoft Plubishers. $590 \mathrm{p}$.

HOPKIN, SP. and READ, HJ., 1992. The biology of millipedes. New York: Oxford University Press. 232 p.

KANAKA, R. and CHOWDAIAH, RN., 1974. Studies on the male reproductive pattern in some Indian Diplopoda (Myriapoda). Symposia of the Zoological Society of London, vol. 32, p. 261-272.

KUBRAKIEWICZ, J., 1987. The ovary structure in two species of millipedes, Iulus scandinavius and Orthomorpha gracilis (Myriapoda, Diplopoda). Zoologica Poloniae, vol. 34, p. 251-260.

KUBRAKIEWICZ, J., 1991a. Ultrastructural investigation of ovary structure of Ophyiulus pilosus (Myriapoda, Diplopoda). Zoomorphology, vol. 110, p. 133-138.

KUBRAKIEWICZ, J., 1991b. Ovary structure and oogenesis of Polyxenus lagurus (L.) (Diplopoda: Pseulaphognatha). An ultrastructural study. Zoologische Jahrbücher (Anatomie). vol. 121, p. 81-93.

MILEY, HH., 1930. Internal anatomy of Euryurus erytropygus (Brandt, Diplopoda). Ohio Journal of Science, vol. 40, p. 229-254.

NADARAJALINGAM, K. and SUBRAMONIAN, T., 1984. Oogenesis in a millipede Spirostreptus asthenes. Zoologischer Anzeiger, vol. 212, no. 3-4, p. 229-239.

NAIR, VSK., 1981. Oocyte developmental and vitellogenesis in Jonespeltis splendidus (Myriapoda: Diplopoda). Journal of Animal Morphology and Physiology, vol. 28, p. 186194.

NEWPORT, G., 1841. The Bakerian lecture: on the organs of reproduction, and the development of the Myriapoda. Philosophical Transactions of the Royal Society of London, vol. 31, p. 99-130.

PINHEIRO, TG., MARQUES, MI. and BATTIROLA, LD., 2009. Life cycle of Poratia salvator (Diplopoda, Polydesmida, Pyrgodesmidae). Zoologia, vol. 26, no. 4, p. 658-662.

SAREEN, ML. and ADIYODI, KG., 1983. ArthropodaMyriapoda. 1. Oogenesis, oviposition and oosorption. In ADIYODI, KG. and ADIYODI, RG. (Eds.). Reproduc- 
tive biology of invertebrates. Chichester: Wiley \& Sons. p. 497-520.

SEIFERT, B., 1932. Anatomie und Biologie des Diplopoden Strongylosoma pallipes. Zeitschrift fur Morphologie und Okologie der Tiere, vol. 25, no. 2-3, p. 362- 507.

SHELLEY, RM., 2003. A revised, annotated, family-level classification of Diplopoda. Arthropoda Selecta, vol. 11, no. 3, p. 187-207.

VOHLAND, K. and ADIS, J., 1999. Life history of Pycnotropis tida (Diplopoda: Polydesmida: Aphelidesmidae) from seasonally inundated forest in Amazonia (Brazil and Peru). Pedobiologia, vol. 43, p. 231-244.

VOIGTLÄNDER, K., 2000. Observations on nest construction by Polydesmus denticulatus C. L. Koch, 1847.
Abhandlungen und Berichte des Naturkundemuseum Görlitz, vol. 72, p. 235-237.

WARBURG, MR. and GEALEKMAN, O., 2000. Ovarian structure and oogenetic cycle in the millipede Catamicrophyllum caifanum (Diplopoda: Iulidae). Journal of Zoology, vol. 250, p. 79-85.

YAHATA, K. and MAKIOKA, T., 1994. Phylogenetic implications of structure of adult ovary and oogenesis in the penicillate diplopod, Eudigraphis nigricans(Miyosi) (Diplopoda: Myriapoda). Journal of Morphology, vol. 222, p. 223-230.

YAHATA, K. and MAKIOKA, T., 1997. Phylogenetic significance of the structure of adult ovary and oogenesis in a primitive chilognathan diplopod, Hyleoglomeris japonica Verhoeff (Glomerida, Diplopoda). Journal of Morphology, vol. 231, p. 277-285. 